\title{
Gender Aspect of Disaster Management in India
}

\author{
Amit Sinha $^{1}$, Dr. Rajlaxmi Srivastava ${ }^{2}$ \\ ${ }^{1}$ Research Scholar, Institute of Management, Commerce and Economics, \\ Shri Ramswaroop Memorial University, Lucknow- Deva Road, UP. \\ ${ }^{2}$ Associate Professor, Institute of Management Commerce and Economics, \\ Shri Ramswaroop Memorial University, Lucknow- Deva Road, UP.
}

\begin{abstract}
The various role definitions of male and female in day to day life show that they are favorably titled towards male population when it comes to resource allocation, daily job roles of earning livelihood or even using available resources for the family. This makes them vulnerable, and impact of disasters increase pre-existing vulnerabilities in everyday life of women.In case of Natural Disasters, the role of female cannot be ignored as a victim of the event and as the partner in the process of repair and rebuilding of the affected area. As a victim they face more hardships in the form of resource crunch, as priority of everything is reserved for male members, females get access to food or medical relief at the last ladder of support.Further, in calamities and disasters they get additional burden of taking care of kids, arrangement and safety of food and water, taking care of ailing or injured family members etc. even the safety of females in such situation is a big cause of concern. Geographical and socio-cultural diversity of India also gives different dimension to these gender based vulnerability of females. There is ample scope of involvement and empowermentof the women in Disaster Risk Management and Mitigation program at every level to reduce the vulnerability of the society and capability to bounce back to normalcy in lesser time span. The proposed paper attempts to find out the areas in Disaster Management wherein females can be protected and can be banked upon to support the development process in affected areas with limited resources.
\end{abstract}

Keywords: Gender, Disaster Management, Impact of Disaster, Disaster Risk Management, Empowerment of Women

\section{Introduction}

Disasters and their impacts show the pre-existing social inequalities of caste, class, ethnicity,sexualities, disability and age, with gender cutting across in all of them. In the wake of a disaster, gender relations and issues are generally considered to be irrelevant or as a luxury. The differential impact of disasters on men/boys and women/ girls are not taken into account while responding to the needs of the affected community. Further, resource distribution in a post disaster scenario, which is intended for the entire population of a disaster-affected area, rely on the existing structures of distribution that reflect the conventional structure of the society giving less freedom for females, and hence, giving less chances to get relief materials or support.

The potential contributions that women can offer to disaster risk reduction around the world are often overlooked and their leadership in building community resilience to disasters is hardly highlighted. This is reflected in the lack of a platform for women in formal disaster management organisations for sharing their needs, experiences and priorities. Gender differenceis again tilted towards men to assume greater responsibilities as per social expectations. Masculinity norms may encourage risky and heroic action during the search and rescue period, debris removal, and reconstruction, and deter men from approaching agencies for assistance and seeking counseling later. Therefore, the differential needs; vulnerabilities and capacities of men/boys and women/girls need to be taken into account while designing any intervention in the pre-as well as post-disaster scenario [1].

\section{Review of Literature}

\subsection{Concept of Gender, Disaster and Disaster Management:}

The words 'Gender' and 'Sex' are two interchangeably used words, but they are totally two different concepts from each other. 'Sex' is a biological term to refer any human or animal being either male or female depending upon their reproductive organs or genes. The Term 'Gender'can be seen as a Social construct through which men and women are categorized into two sections having specified normsto behave in certain socially acceptable roles. In other words individuals are born female or male, but learn to be girls and boys who grow into women and men. They are taught what the appropriate behavior and attitudes, roles and activities are for them, and how they should relate to other people. This learned behavior is what makes up gender identity and determines gender roles [2]

The term "Disaster" has been defined in many ways by scholars and various Developmental and humanitarian communities. We can understand the term 'disaster' better if we take time to some allied words such as extreme events, hazards, vulnerability, and environmental stress. Those events or accidents, whether caused by natural processes or human factors, are called extreme events which occur very rarely and aggravate natural environmental processes to cause disaster for human society. Hazard is a dangerous human activity or condition that may cause loss of life, injury or other health impacts, property damage, loss of livelihoods and services, social and economic disruption, or environmental damage [3]. The Term 'Vulnerability' is thecharacteristics and circumstances of a community, system or asset that make it susceptible to the damaging effects of a hazard [4]. While the Wikipedia Encyclopedia explicitly says, "The word disaster is the combination of two Latin 


\section{International Journal of Science and Research (IJSR) \\ ISSN (Online): 2319-7064}

Index Copernicus Value (2015): 78.96 | Impact Factor (2015): 6.391

words - 'Dis' and 'Astro' means "bad star". Therefore, disaster can be simply referred to as the unforeseen calamities caused by planetary movements or placements.Disasters occur rapidly, instantaneously and indiscriminately. ... All the extreme events are hazards but not all the hazards are disasters. A hazard may become disaster only when it strikes the inhabited area. In Disaster Management Act, 2005 of India, Disaster is defined as a catastrophe, mishap, calamity or a grave occurrence in any area arising out of natural or manmade causes, or by accident or negligence, which results in substantial loss of life and human suffering or damage to, or destruction of, or degradation of environment, and is of such a nature, or magnitude as to be beyond the coping capacity of the affected community of the affected area.

The term "Disaster Management" is a collective term referring to all aspects of planning and responding to disasters, including both pre and post- disaster activities. It may refer to the management of the both, the risks and consequences of disasters. When a hazard is not managed properly, it turns into a disaster [5]. We can say disaster to be directly proportional to the product of hazard and vulnerability, i.e. Disaster = Hazard X Vulnerability [6]

\section{Objective of the Study}

3.1 To explore the impact of disasters in light of Gender Difference.

3.2 To explore and identify the types of problem faced by females in the three disaster phases: pre, post and during catastrophe.

3.3 To suggest capacity building means to remove gender biasness and giving due consideration to specific needs of female population in coping with disasters.

\section{Research Methodology}

This paper iswritten using descriptive, analytical and doctrinal research methodologies. Descriptive method is applied where things are of introductory and observatory in nature. Here the work is based on the Journals, United Nation's Guidelines and other materials of international relevance and the method applied is doctrinal. Regarding analysis of legal provisions, economic status and the prevailing methods to remove gender biasness and capacity building of females in disaster prone and disaster hit areas, the method applied is analytical.

\section{Differential Impact of Disasters on Women and Men}

The literature on gender and disasters powerfully documents the importance of gender considerations in disaster prevention, emergency response, rehabilitation, and reconstruction. The section below presents some of the major issues related to gender and disaster. While this decision places them within a particular disaster phase, many gender issues may cross-cut all phases of the disaster process. We can see the differential impact of disaster on women and men in pre and post disaster event in the given chart -

\begin{tabular}{|c|c|c|}
\hline \multicolumn{3}{|c|}{ Some Global gender Issues and their Patterns } \\
\hline \begin{tabular}{|l} 
Key Issues in \\
Gender and \\
Disasters Phase
\end{tabular} & Issues & Examples \\
\hline Pre-Disaster & $\begin{array}{l}\text { - Vulnerability } \\
\text { - Risk Perception }\end{array}$ & $\begin{array}{l}\text { Pregnant/lactating } \\
\text { women } \\
\text { Men in Search \& Rescue } \\
\text { - Willingness to Evacuate }\end{array}$ \\
\hline Emergency & - Coping Strategies & $\begin{array}{l}\text { - Mobilizing } \\
\text { Networks } \\
\text { Temporary Migration } \\
\text { Telling } \\
\text { Goods }\end{array}$ \\
\hline Rehabilitation & $\begin{array}{l}\text { - Needs and Priorities } \\
\text { - Social Composition } \\
\text { - Creation of New } \\
\text { Vulnerabilities }\end{array}$ & $\begin{array}{l}\text { - Agriculture vs. Health } \\
\text { - Greater Female Headship } \\
\text { - Sexual/Physical Violence } \\
\text { - Alcohol } \\
\text { Abuse/Aggression }\end{array}$ \\
\hline Reconstruction & $\begin{array}{l}\text { - New Gender Roles } \\
\text { - Gender Relationships }\end{array}$ & $\begin{array}{l}\text { - Land Tenure Changes } \\
\text { New Domestic Roles } \\
\text { "Women's" Programs } \\
\text { and Male Exclusion }\end{array}$ \\
\hline
\end{tabular}

Global Patterns of Gender and Disaster [7]

\subsection{Pre-Disaster: Prevention and Mitigation.}

To have a better disaster prevention and mitigation program we need to understand thatnot all women can be termed as vulnerable but yes many of them are vulnerable for biological reasons such as physical disability, pregnancy, lactation, age status etc. inferior social position of women also makes them vulnerable to disasters. Further, there are cultural vulnerabilities also as women's restricted mobility and cultural taboos that prohibit women from engaging in certain activities, such as house construction. Women aremore likely to perceive the probability of disaster recurrence. Thus, women are often better suited to participate in disaster preparedness planning and community organizing. The exclusion of women from disaster preparedness planning and dependency on males can have disastrous consequences for men, women, and children in disasters [8].

\subsection{During: Emergency and Rehabilitation Phases}

It has been a regular observation that women tend to cope well with the situations by forming informal groups and by taking help of formal relief agencies in order to meet needs of family, children, and the larger community. Health wise also women need special help like obstetric-gynecological care or feminine hygiene products. Loss of male earning members results in more female-headed households and the economic vulnerabilities. Providing food and non-food assistance should be better targeted to women, who make sure that resources are equitably allocated. Men are less likely to understand the complex household needs and are more likely to sell relief material for their personal benefit.

\subsection{Post Disaster: Reconstruction and Transformation}

In the post-disaster transformation, two major challenges are faced by women in form of increased women's participation in decision-making and providing capacity-building in nontraditional areas. Sometimes while planning the post-disaster 


\section{International Journal of Science and Research (IJSR) \\ ISSN (Online): 2319-7064}

Index Copernicus Value (2015): 78.96 | Impact Factor (2015): 6.391

transformation, family equation gets a hit as more recognition and power to females hurts their counterparts and in the long-run reconstruction and transformation program for society face threat of destabilizing families, increasing domestic violence, and augmenting male alcohol abuse [9].

\section{Engendering Disaster Management}

\subsection{Gender and Disasters}

The relief aid is provided with an approach that 'one blanket will fit all'. Temporary shelters are put into place for survivors without any consideration of issues like sanitation; specific clothing and toiletries as vital supplies required by women survivors. An effective relief management strategy needs to be built upon two pillars, firstly, addressing the specific needs of women, and secondly, ensuring their participation and involvement in the management process [10].

Disasters affect women and men differently because of the differences in their capacities, needs and vulnerabilities. UN/ISDR indicates that women are more vulnerable in disasters and they are the most affected. The poor and predominantly female and elderly populations are seen as more economically vulnerable as they suffer proportionally larger losses with limited capacity to recover [11]. Enarson [12] identifies the following points as the reasons for women's higher vulnerability in disasters.

6.1.1 Women have less access to resources.

6.1.2 Womenare victims of the gendered division of labour.

6.1.3 Women are primarily responsible for domestic duties and they do not have the liberty of migrating to lookfor work following a disaster.

6.1.4 disasters increase women's vulnerability not only because they increase female headed households but sexual and domestic violence are also increased following a disaster.

As Ariyabandu and Wickramasinghe [13] indicate, a gender perspective should be integrated into all disaster reduction policies and measures in order to decrease women's susceptibility in disasters. It is important to empower women to have an increased role in leadership, management and decision making positions because women are not only victims of disasters but they can act as agents of change in disaster reduction planning [14].

\subsection{Gender Mainstreaming}

Disaster robs the survivors, both men and women, of their livelihood. Scarcity of resources or death of male bread earner, women previously engaged in household work may feel the need to engage in paid work; but may not be able to do so because lack of childcare centers with timings not suiting to their work schedules. Women who lost both their husbands and their assets may not receive compensation for their losses [15].

The Platform for Action (PFA) at the Fourth World Conference on Women in Beijing in 1995 brought up the concept of gender mainstreaming, the commitment to integrate gender perspective in all forms of development and political processes of governments [16]. UNISDR elaborates gender mainstreaming as the process of bringing a gendered perspective into the mainstream activities of governments at all levels, as a means of promoting the role of women in the field of development andintegrating women's values into development work. [17]

As the United Nations Office of the Special Adviser on Gender Issues and Advancement of Women [18] explains, gender mainstreaming can promote gender equality and women's empowerment, particularly where there are glaring instances of persistent discrimination of women and inequality between women and men.However, promoting gender mainstreaming is a long, slow process requiring inputs on many fronts over a long period of time, including advocacy, advice and support, competence development, development of methods and tools and vigilance in following up and evaluating progress [19].

\subsection{Gender Mainstreaming in Disaster Reduction}

In 1991 Bangladesh cyclone, people who received the early warning ignored it because cyclones occurring after the 1970 disaster had not caused much devastation. In the ensuing procrastination, women who had comparatively less knowledge about cyclones and were dependent on male decision- making, perished, many with their children, waiting for their husbands to return home and take them to safety. Therefore, dissemination of timely and meaningful warning to both women and men is the first step in mainstreaming gender in emergency response [20]. The United Nations International Strategy for Disaster Reductionrecommends that efforts should be made to increase a gender balance in decision-making positions to deal with disaster risk management.

\section{Conclusion and Suggestions}

Vulnerability of women and due to their roles and the consequences of disasters emphasize the need to achieve gender equality in disaster reduction and integrate a gendered perspective to all policies and measures implemented in disaster management context. Some actionable points can be as under -

7.1 Ensure that needs-assessment and response teams are gender balanced.

7.2 Involvement of women in early warning dissemination system.

7.3 Do not register beneficiaries solely based on male heads of household.

7.4 Psychosocial support services should be part of disaster management activities.

7.5 Involve men and women from diverse groups actively in the planning, design, construction, and maintenance of mitigation works [21].

Since disaster reduction and development have a close inter relationship, gender mainstreaming gains importance as we cannot ignore the role of women in disaster reduction.There is ample scope to involvement and empowerment of the women in Disaster Risk Management and Mitigation program at every level to reduce the vulnerability of the society and capability to bounce back to normalcy.

\section{Volume 6 Issue 7, July 2017 www.ijsr.net}




\section{Limitation of the Study}

This paper is written with an objective to conceptually explore the condition of female gender in the present setup. The time constraint, scatter affected areas and logistical issues were the binding factors to forgo empirical research on the issue.

\section{Future Scope of the Study}

The aspects discussed in this paper are very relevant in the light of gender sensitive andequitable approaches in capacitydevelopment covering all aspects ofdisaster management in India's first National Disaster Management Plan, 2016 and global thrust on integration efforts of Disaster Reduction in Developmental plans through Sendai Declarations and Sustainable Development Goals (SDG) 2015-2030. More studies can be done on this aspect, as the area of concern is globally acknowledged to include women in planning and implementation roles to have robust acceptable system in place.

\section{References}

[1] AjinderWalia, Gender and Disaster Management: A Training of Trainers (TOT) Module (New Delhi: National Institute of Disaster Management, 2015) at vii.

[2] Ibidem at 2.

[3] UNISDR Terminology on Disaster Risk Reduction (Geneva, Switzerland : UNISDR, 2009) at 17.

[4] UNISDR, Supra n.3 at 30.

[5] Walia, Supra n. 1 at 27.

[6] Ibidem at 27.

[7] World Bank Institute Distance Learning, Natural Disaster Risk Management Program, "Gender Aspects of Disaster Recovery and Reconstruction." Available at http://worldbank.mrooms.net/ file.php/349/Readings/Reading1-HurricaneGender_Aspects_of_Disaster_Management.pdf (Accessed on - 23.11.16).

[8] Ibidem at 4.

[9] Ibid at 5.

[10] Walia, Supra n. 1 at 83.

[11] KanchanaGinige, DilanthiAmaratunga, Richard Haigh, "Gender Mainstreaming in Disaster Reduction: Why and How?" Available athttp://usir.salford.ac.uk/9808/1/Pages_from_ 105_Ginige_KN_et_al_Role_of_women_leaders_in_the _UK_construction_industry_Bear_2008.pdf(Assessed on 23.11.16).

[12] Enarson, E. (2000) "Gender and Natural Disasters", IPCRR Working Paper no.1, International Labour Organisation. Referred in Supra n 13.

[13] M.M. Ariyabandu, M. Wickramasinghe, Gender Dimensions in Disaster Management - A Guide for South Asia (Colombo: ITDG South Asia, 2003). Referred in :Supra n.13.

[14] Supra n.11.

[15] Walia, Supra n. 1 at 88.

[16] "Supporting Gender Mainstreaming", Office of the Special Adviser on Gender Issues and Advancement of Women, (2001).Available http://www.un.org/womenwatch /osagi/pdf/report.pdf (Accessed on 23.11.2016).

[17] "Gender Mainstreaming", European Commission, (1996). Referred in :Supra n.13.

[18] Supra n.16.

[19] Ibidem.

[20] Walia, Supra n.1 at 94.

[21] "A Practical Guide to Gender-Sensitive Approaches for Disaster Management” (Geneva/ Switzerland, International Federation of Red Cross and Red Crescent Societies, 2010).Available athttp://www.ifrc.org/PageFiles/96532/AGuideforGendersensitiveapproachtoDM.pdf (Accessed on 23.11.2016). 